\title{
Study on the Use of Ionizing Radiation for the Preservation of Spices
}

\author{
Amal Hassan Alshawi, $\mathrm{PhD}$ \\ Nutrition and Food Sciences Department,Princess Norah bint Abdulrahman University, Riyadh, KSA
}

\begin{abstract}
Black pepper (Piper nigrum L.) and clove (Eugenia caryophyllata) were treated with gamma radiationdoses (5.0, 10.0, $20 \mathrm{kGy}$ )andstored for six months. The results showed an increase in the dry matter content of black pepper during the storage period withvalues of $91.61 \pm 2.36 \%, 92.59 \pm 2.39 \%$, and $92.62 \pm 2.37 \% \mathrm{w} / \mathrm{w}$ at $5.0,10.0$ and $20.0 \mathrm{kGy}$, respectively, compared with $91.41 \pm 2.25 \% \mathrm{w} / \mathrm{w}$ for the non-irradiated sample. Also, there was an increase in the dry matter content ofcloves, withvalues of $91.34 \pm 2.35 \%, 92.55 \pm 2.39 \%$, and $92.87 \pm 2.37 \% \mathrm{w} / \mathrm{wat} 5.0,10.0$ and $20.0 \mathrm{kGy}$, respectively, compared with a value of $91.34 \pm 2.35 \% \mathrm{w} / \mathrm{w}$ for the non-irradiated sample. However, a significant decrease in the total of essential oil which detected with increasing irradiation dose during the storage periods for black pepper and clovewith values of $97.42 \pm 0.22 \%, 98.65 \pm 0.27 \%$ and $96.88 \pm 0.23 \%$ at 5.0, 10.0 and $20.0 \mathrm{kGy}$, compared with $98.80 \pm 0.22 \%$ for the non-irradiated control. also, $94.33 \pm 0.34 \%, 94.20 \pm 0.34 \%$ and $94.10 \pm 0.35 \%$ at $5.0,10.0$ and $20.0 \mathrm{kGy}$, compared with $95.98 \pm 0.39 \%$ for the non-irradiated control samples, respectively. Anirradiation dose of $10.0 \mathrm{kGy}$ with three months of storage led to the highest increase in the amount of total essential oils of black pepper and clovewith values $98.89 \pm 0.25 \%$ and $95.94 \pm 0.34 \%$, respectively. A dose of $10 \mathrm{kGy}$ eliminated the total bacterial count, as well as the yeast, while a dose of only $5 \mathrm{kGy}$ was required to reduce the contamination. During six months of storage, the radiated spices were found to retain good microbiological quality.
\end{abstract}

Keywords: Black pepper,chemical composition, clove,microbial quality, Radiation,spices.

\section{Introduction}

Spices are widely used to improve the taste and flavour of food, and they have a range of medicinal properties; some are known as antioxidants. Among the spices, black pepper (Piper nigrum L.) and clove (Eugenia caryophyllata) have been traditionally used for the treatment of many ailments[1]. Black pepper is acommonly used spice worldwide, especially in India and Southeast Asia. It is composed of several chemical constituents and includes some alkaloids,such as piperine and its three stereoisomers, isopiperine, chavicine and isochavicine[2][3] . Cloves are the aromatic dried flowers of a tree in the family Myrtaceae. The important chemical compounds in cloves are eugenol, tannins, flavonoids, triterpenoids and several sesquiterpenes[1]. However, spices present a potential source of microbial pollution in foodstuffs to which they are added. This primarily occurs in developing countries where harvest and storage conditions are poorly controlled with respect to food hygiene. Thus, the foodstuffs may have been exposed to a high level of contamination by mesophiles, hyphomycetes, faecal coliforms, and sporogenic and asporogenous bacteria [4] .

Irradiation is a method that uses radiant energy to forusefulpurposes, such as disinfection, shelf life improvement by the inactivation of spoilage organisms, and the improvement of the safety of spices by inactivating food-borne pathogens [5].Y-Ray irradiation is now internationally recognized as an effectivestandard and safe sterilization technique for maintaining the long-term quality of spices [6].This method decreases the risk of microbiological contamination and prolongs the shelf life of foodstuff [7]. In addition, it reduces post-harvest losses, ensures hygienic quality and facilitates food product trading[8]. The established community list provided by the Directive 1999/3/EC itemizes food ingredients and foods that can be treated by ionizing radiation and gives the maximum overall average absorbed dose as $10 \mathrm{kGy}$ for dried aromatic herbs, spices and vegetable seasonings[9]. The U.S. Food and Drug Administration (FDA) limit for culinary spices, herbs, seeds, vegetable seasonings cannotsurpass $30 \mathrm{kGy}$ [4][10] .No significant chemical changesfound inirradiatedblack pepper and clove with doses of 7 and $10 \mathrm{kGy}$.However, the microbiological results revealed that the aerobic platecount was reduced by 2.5 to 4.0 $\log$ cycles (mean values) with a dose of $7 \mathrm{kGy}$, while $10 \mathrm{kGy}$ provided the most satisfactory hygienic results,to maintain a good market condition for at least one year[11]. Most significant changes in the chemical composition and in the microbiological quality of black pepper were observed after an ionizing radiation treatment of up to 30 $\mathrm{kGy}$. The highest dose of irradiation used (30 kGy) affected many compounds by increasingthe ratio of many 
oxygenated compounds (trans-sabinene hydrate, 3,4 dimethylstyrene, cyclohexenol, p-cy-men-8-ol, terpinen-4-ol, $\alpha$ terpineal,eucarvon, piperitenon, $\alpha$-terpineol,piperiton,spathulenol, and undecanone) compared with the control[12] [13] .Theresearchgoal is to study the effects of gamma rays at doses of 5, 10, and 20 kGyduring the storage periods on the chemical analysis and microbial quality of black pepper and clove.

\subsection{Spice samples}

\section{Materials And Methods}

- The flowering vine, black pepper (Piper nigrum), is in the family Piperaceaeand is cultivated for its fruit[12][14].

- The aromatic dried flower, clove (Eugenia caryophyllata), is from a tree in the family Myrtaceae[15].

- The samples were dried and used as a spice and seasoning[16][17].

The samples were purchased from a local market in Riyadh, Saudi Arabia.Then, they were washed and thoroughly dried by exposing them to cold air.The samples were subsequentlyground and placed in polyethylene bags ( $250 \mathrm{~g}$ per bag).The bags were separatedinto groups forthe irradiation process, the chemical analysis and the evaluation of the microbial quality (five replicates for each group)[6].

\subsection{Irradiation process}

The irradiation process was achieved using 60-cobalt gamma raysin a gamma cell-220 at King Abdul Aziz City for Science and Technology (KACST) in Riyadh. The dose rate was $14.2514 \mathrm{kGy} / \mathrm{h}$ at the time of the experiment. The samples were exposed to different gamma radiation doses of 5, 10, and $20 \mathrm{kGy}$; in addition, there was an untreated control.

\subsection{Chemical analysis}

\subsubsection{Preparing samples for chemical analysis}

Samples of black pepper and clove werestored for chemical analysis under laboratory conditions (dark , at 6 ${ }^{\circ} \mathrm{C}$, humidity of $60 \%$ for 0,3 and 6 months).

\subsubsection{Dry matter content}

The dry matter content was estimated usinga 10 -g sample, which was dried in a hot air oven at $130^{\circ} \mathrm{C} \pm$ $1{ }^{\circ} \mathrm{C}$ in pre-weighed dishes until reaching a constant weight. Each dish containing the dried sample was transferred to a desiccator and was cooled to room temperature. Then, the samples were weighed, and the dry matter content (percent) was calculated fromthe weight loss [18] (Association of Official Analytical Chemists 1990).

\subsubsection{Essential oil content}

The essential oils were extracted from the treated samples of black pepper and clove, which were then injected into a gas-liquid chromatograph (GLC).

\subsubsection{Extraction of essential oils}

Double-distilled water was added to a flask containing the powder samples. A continuous steam distillationwas performed for $3 \mathrm{~h}$. The oil and the steam distillate were isolated; the oil was dried over anhydrous sodium sulphate [19].

\subsubsection{GLC analysis of essential oils}

Authentic essential compounds were acquired from Dragoc (Holzminden, Germany). The essential oil was analysed using a PyeUnicam gas chromatograph with dual Flame Ionization Detectors (FID) andthe chromatograph fitted with a coiled glass column $(1.5 \mathrm{mx} 4 \mathrm{~mm})$.It packed with Diatomite C100-120 mesh and coated with $10 \%$ PEGA. Theoven temperature was set to increase from $60^{\circ} \mathrm{C}$ to $180^{\circ} \mathrm{C}$ at a rate of $4^{\circ} \mathrm{C}$ per minute. The isothermal operation was held at $180^{\circ} \mathrm{C}$ for 15 minutes. The detector temperature was $220^{\circ} \mathrm{C}$, and the injector temperaturewas $30^{\circ} \mathrm{C}$. The gas flow rates forhydrogen, nitrogen, and air were 33,30 , and $30 \mathrm{ml} / \mathrm{min}$, respectively. The extracted essential oils were mixed with their major components and injected into the GLC to verify the resultant peaks[20]. The samples were analysed in triplicate, and the areas under the peak were calculated [21] .

\subsection{Microbial content assay}

According to the A.P.H.A 1985 technique, the microbial content of the spice samples was evaluated usingthe total plate count (TPC) of the microbial content of bacteria, and yeast. The estimation was performed using $10 \mathrm{~g}$ of each spice and with the addition of $90 \mathrm{ml}$ of a sterilized physiological substance (saline) to obtain a $1 / 10$ dilution. 
The required dilution was prepared, and the following AJAR culture medium was used:

$\begin{array}{ll}\text {-Bacto plate count agar } & 15 \mathrm{~g} \\ \text {-Trypone } & 5 \mathrm{~g} \\ \text {-Bactodextrose(Glucose) } & 1 \mathrm{~g} \\ \text {-Bacto yeast extract } & 2.5 \mathrm{~g} \\ \text {-pH } & 7 \pm 0.2\end{array}$

After sterilization, the AJAR medium was placed in petri dishes thatwere prepared in advance; then, sterilized medium was placed in the dishes, and they were incubated at $35 \mathrm{C}$ for $48 \mathrm{~h}$. Five replicates wereprepared for each test analysis, and the total count was calculated for every $1 \mathrm{~g}$ of the non-radiated and radiated spice samples.

\subsection{Statistical analysis}

The data were subjected to analysis of variance (ANOVA) for the completely randomized block design that was used. Averages and least significant differences were calculated by the SAS system version 9.1.3 (Cary, $\mathrm{NC}$ ). The results were expressed as the mean \pm standard deviation. A value of $\mathrm{P}<0.05$ was considered significant [22]

\section{Results And Discussion}

Table 1 shows the effects of irradiation and storage on the changes in dry matter content during the storage of irradiated black pepper and clove. The dry matter content increased by approximately $4 \% \mathrm{w} / \mathrm{w}$ during the storage of these spices. The black pepper values were $91.61 \pm 2.36 \%, 92.59 \pm 2.39 \%$, and $92.62 \pm 2.37 \% \mathrm{w} / \mathrm{w}$ at $5.0,10.0$ and $20.0 \mathrm{kGy}$, respectively,compared with $91.41 \pm 2.25 \% \mathrm{w} / \mathrm{w}$ of the non-irradiated control. An increase in the clove dry matter content was also observed with values of $91.34 \pm 2.35 \%, 92.55 \pm 2.39 \%$, and $92.87 \pm 2.37 \% \mathrm{w} / \mathrm{w}$ at $5.0,10.0$ and $20.0 \mathrm{kGy}$, respectively, compared with $91.34 \pm 2.35 \% \mathrm{w} / \mathrm{w}$ of the non-irradiated control.These findings are in agreement with those described bySuhaj et al., 2006, who noticed an increase in dry matter content during the storage of irradiated spice under laboratory conditions[6].Studies illustrated that radiation exposure at different doses affect the final dry matter content of this spice[23][24].The effects of gamma irradiation on the essential oils in the spice samples during thestorage period are shown in Tables 2 and 3.Table 2 shows a decrease in the amount of total essential oils content inblack pepper after six months of storagewith values of $97.42 \pm 0.22 \%, 98.65 \pm 0.27 \%$ and $96.88 \pm 0.23 \%$ at $5.0,10.0$ and $20.0 \mathrm{kGy}$, respectively, compared with $98.80 \pm 0.22 \%$ for the non-irradiated control. The total concentrations of the identified compounds decreased gradually with increasing irradiation dose during the storage periods; a dose of $10.0 \mathrm{kGy}$ and three months of storage for the samples led to the highest increase in the total essential oils of black pepper $(98.66 \pm 0.25 \%)$.

InTable2, the primary compounds innone irradiated black pepper sampleswhich identified as essential oilswere Limonene $(22.80 \pm 0.12 \%)$, Sabinene $(22.30 \pm 0.23 \%)$ and D-carene $(15.90 \pm 0.13 \%)$.Our data agree with Suhaj et al. (2006)[6]and Franco et al.(2004)[25].Limonene appears to account for the highest proportion of essential oils in the tested black pepper at different irradiation doses during the storage periods, as was observed from the results by Emam et al. (1995)[26]. As shown inTable3, a reduction in the amount of total essential oils contentin clove was shown after six months of storage, with values of $94.33 \pm 0.34 \%, 94.20 \pm 0.34 \%$ and $94.10 \pm 0.35 \%$ at $5.0,10.0$ and $20.0 \mathrm{kGy}$, respectively, compared with $95.98 \pm 0.39 \%$ for the non-irradiated control samples. The total concentrations of the identified compounds decreased gradually with increasing irradiation dose during the storage periods; a dose of $10.0 \mathrm{kGy}$ and three months of storage led to the highestamount of total essential oils of clove(95.94 \pm 0.34$)$. Eugenol $(73.50 \pm 1.34 \%)$ and Eugenol Acetate $(10.81 \pm 0.89 \%)$ were the major essential oil components in clove in none irradiation samples, and the identified compounds in clove in this study agree withthe results Abozid et al. (2013)[15] andAlma et al., (2007)[27].Eugenol appears to account for the highest proportion of the tested clove essential oils of different irradiation doses during the storage periods, as was observed from the results ofGuan et al.(2007)[28] and Chaieb et al.(2007)[29].The results demonstrated that the essential oils in spices are radiosensitive, especially at high doses. Previous studies showed that the essential oils in spices are heat sensitive,especially at temperatures above $90^{\circ} \mathrm{C}$ [30] .The irradiation process at low doses is used asa cold, physical treatment for food because no significant heating occursafter treating the samples. Therefore, irradiation has no direct effect on the flavour of compounds; however, it can indirectly affect the flavour by oxidation or hydroxylation of the terpene aromatic ring due tothe production of free radicals in the food[31].These radicals can react with terpenes to produce terpene alcohols, as indicated in the study on the gamma irradiation of spices[10].Terpenes, which are incorporated in most of the essential oils, have the same skeletal structure but have different functional groups, such as- $\mathrm{CHO}$, - $\mathrm{OH}$, or $-\mathrm{COOH}$. Therefore, configurational changes can occurfollowing high dose irradiation, including changes in the locus of the double bond and the functional group,performing in different 
components [32].The results of the microbiological aspects of this study are presented in Table 4. The difference between irradiated samples and non-irradiated (control) samples indicated that most microbial counts were high for the control samples and low for the irradiated ones. Thus, the use of irradiation treatment might affect the microbial counts. It was noticed that gamma irradiation initiated a substantial reduction in all of the tested microorganisms, and this reduction was proportional to the irradiation dose. The lowest irradiation dose of $5 \mathrm{kGy}$ decreased the total aerobic bacterial counts of black pepper and clove to $3.1 \times 10^{3}$ and $2.5 \times 10^{2}$, respectively, whereas the total aerobic bacterial counts decreased to $<10$ with the doses of 10 and $20 \mathrm{kGy}$ during the storage periods. In addition, black pepper and clove irradiated with various doses of $\gamma$-irradiation showed a considerable reduction in the total yeast and mould count,reaching $<10$.Sharma et al. (1984)[33] revealed that the bacterial counts of commercially obtainable spices rangedfrom $10^{2}$ to $10^{7} / \mathrm{g}$, whereas the fungal counts varied from $10^{2}$ to $10^{3} / \mathrm{g}$. These findings are consistent with those stated by Farkas (1988)[32], who noticed that spices might not be suitable for the growth or long-term survival of the bacterial counts. The higher reduction in total aerobic bacterial counts in the spice samples might be due to the direct effect of radiation and the indirect effect of radiolysis, which is greater in control samples than in irradiated samples. Irradiation is used to improve the microbiological safety of foods. The irradiation showed a feasible process because the doses necessary to ensure good microbiological quality did not change the overall quality of the Spice[11]. There was an increase in the shelf life of the irradiated when compared to the non-irradiated samples [34][35][36].

\section{Conclusion}

Radiation treatment increased the total of dry matter content during the storage for black pepper and clove. But it decreased the total amount of essential oils in the treated samples and In addition, Gamma irradiation caused a great reduction in all tested microorganisms, and this decrease was proportional to irradiation dose.The results of this study show a convenient method of irradiation that is used for food preservation, especially the spices.

\section{Recommendation}

Since no specific dose was found to be advantageous for the parameters tested, the present study recommends utilizing $\gamma$-radiation for black pepper, clove and other spices. Further,there is a need to evaluate the in vivo assays after feeding the experimental animals the irradiated spices.

\section{References}

[1]. Nemtanu MR, Brasoveanu M, Meltzer V, Pincu E, Oproiu C (2009) Thermal analysis of some phytotherapeutic products irradiated with electron beam. J Therm Anal Calorim 97:309-313. doi: 10.1007/s10973-008-9624-8.

[2]. Kolhe SR, Borole P, Patel U (2011) Extraction and evaluation of piperine from Piper Nigrum Linn. Inter J ApplBiol Pharma Tech 2:144149.

[3]. Namjoyan F, Hejazi H, Ramezani Z (2012) Evaluation of drying process on the composition of Black pepper Ethanolic extract by high performance liquid chromatography with diode array detector. Jundishapur J Nat Pharm Prod 7:163-167. doi: 10.17795/jjnpp-5177.

[4]. Bendini A, GallinaToschi T, Lercker G (1998) Influence of $\gamma$-irradiation and microwaves on the linear unsaturated hydrocarbon fraction in spices. Z-LebensmUntersForschung A 207:214-218. doi: 10.1007/s002170050321.

[5]. Calado T, Venâncio A, Abrunhosa L (2014) Irradiation for mold and mycotoxin control: a review. Compr Rev Food Sci Food Saf 13:1049-1061. doi: 10.1111/1541-4337.12095.

[6]. Suhaj M, Rácová J, Polovka M, Brezová V (2006) Effect of $\gamma$-irradiation on antioxidant activity of black pepper (Piper nigrum L.). Food Chem 97:696-704. doi: 10.1016/j.foodchem.2005.05.048.

[7]. Oh KN, Lee SY, Lee HJ, Kim KE, Yang JS (2003) Screening of gamma irradiated spices in Korea by using amicrobiological method (DEFT/APC). Food Control 14:489-494. doi: 10.1016/S0956-7135(02)00108-1.

[8]. Sadecka J (2007) Irradiation of spices - a review. Czech J Food Sci 25:231-242.

[9]. Directive 1999/3/EC of the European Parliament and of the Council of 22 February 1999 on the establishment of a community list of foods and food ingredients treated with ionising radiation. Official Journal of the European Communities 42:L66.

[10]. Code of Federal Regulation: 21CFR179: Irradiation in the production, processing and handling of food, Title 21 (Vol. 3). Revised as of April 1, 2004.

[11]. Narvaiz P, Lescano G, Kairiyama E, Kaupert N. (1989) Decontamination of spices by irradiation. J Food Saf 10:49-61. doi: $10.1111 / \mathrm{j} .1745-4565.1989 . t b 00007$.

[12]. Sadecka J (2010) Influence of two sterilisation ways, gamma-irradiation and heat treatment, on the volatiles of Black pepper (Piper nigrum L.). J Food Sci 28:44-52 [In Czech].

[13]. Polovka M, Brezová V, Staško A, Mazúr M, Suhaj M, Šimko P (2006) EPR investigations of gamma-irradiated ground black pepper.Radiat Phys Chem 75:309-321. doi: 10.1016/j.radphyschem.2005.07.007.

[14]. Sruthi D, Zachariah J, T, Leela NK, Jayarajan K (2013) Correlation between chemical profiles of black pepper(Piper nigrum L.) var. Panniyur-1 collected from different locations. J Med Plants Res 7:2349-2357. doi: 10.5897/JMPR2013.4493.

[15]. Abozid MM, EL-Sayed SM (2013) Antioxidant and protective effect of clove extracts and clove essential oil on hydrogen peroxid treated rats. Int J Chem Tech Res 5:1477-1485.

[16]. Ayoola GA, Lawore FM, Adelowotan T, Aibinu IE, Adenipekun E, Coker HAB, Odugbemi TO (2008) Chemical analysis and antimicrobial activity of the essential oil of Syzigiumaromaticum (clove). Afr J Microbiol Res 2:162-166.

[17]. Odugbemi TO (2006) Outlines and pictures of medicinal plants from Nigeria. University of Lagos Press, Lagos, Nigeria, p. 91.

DOI: 10.9790/2402-1009030107 $\quad$ www.iosrjournals.org $4 \mid$ Page


[18]. Association of Official Analytical Chemists (1990) Official methods of analysis, 15th edn. Helrich K (ed.). Association of Official Analytical Chemists, Arlington, VA, p. 99.

[19]. Association of Official Analytical Chemists (1975) Official methods of analysis of the association of official analytical chemists, 2th ed. Horwitz W, Senzel A, Reynolds H, Park DL (eds.) Association of Official Analytical Chemists, Arlington, VA.

[20]. Jayaprakasha GK, Rao LJ, Sakariah KK (2002) Chemical composition of volatile oil from Cinnamomumzeylanicum buds. Z Naturforsch C 57:990-993. doi: 10.1515/znc-2002-11-1206.

[21]. Farag RS, Daw ZY, Abo-raya SH (1989) Influence of some spice essential oils on Aspergillus parasiticus growth and production of aflatoxins in a synthetic medium. J Food Sci 54:74-76. doi: 10.1111/j.1365-2621.1989.tb08571.x.

[22]. Ott L (1984) An introduction to statistical methods and data analysis, 2nd ed. P.W.S. Publishers, Boston.

[23]. Farkas J (2006) Irradiation for better foods. Trends Food SciTechnol 17:148-152. doi: 10.1016/j.tifs.2005.12.003.

[24]. Calucci L, Pinzino C, Zandomeneghi M, Capocchi A, Ghiringhelli S, Saviozzi F, Tozzi S, Galleschi L (2003) Effects of $\gamma$-irradiation on the free radical and antioxidant contents in nine aromatic herbs and spices. J Agric Food Chem 51:927-934. doi: 10.1021/jf020739n.

[25]. Franco RWA, Martin-Neto L, Kato MSA, Furlan GR, Walder JMM, Colnago LA (2004) Identification of irradiation treatment in black pepper by electron paramagnetic resonance. Int J Food SciTechnol 39:395-401. doi: 10.1111/j.1365-2621.2004.00794.x.

[26]. Emam OA, Farag SA, Aziz NH (1995) Comparative effects of gamma and microwave irradiation on the quality of black pepper. Z LebensmUntersForsch 201:557-561. doi: 10.1007/BF01201585.

[27]. Alma MH, Ertas M, Kollmannsberger H (2007) Chemical composition and content of essential oil from the bud of cultivated Turkish clove (Syzygiumaromaticum L.). BioResources 2:265-269.

[28]. Guan W, Li S, Yan R, Tang S, Quan C (2007) Comparison of essential oils of clove buds extracted with supercritical carbon dioxide and other three traditional extraction methods. Food Chem 101:1558-1564. doi: 10.1016/j.foodchem.2006.04.009.

[29]. Chaieb K, Hajlaoui H, Zmantar T, Ben Kahla-Nakbi AB, Rouabhia M, Mahdouani K, Bakhrouf A (2007) The chemical composition and biological activity of clove essential oil, Eugenia caryophyllata (Syzigiumaromaticum L. Myrtaceae): a short review. Phytother Res 21:501-506. doi: 10.1002/ptr.2124.

[30]. Segsarnviriya S, Malakrong A, Kongratarpon T (2005) The effect of gamma radiation on quality of fresh vegetables. In: International Symposium, "New Frontier of irradiated food and non-Food Products" 22-23 September, Bangkok, Thailand.

[31]. Urbain WM (1978) Food irradiation. Academic Press, Zürich, Switzerland, p 351. doi: 10.1016/S0065-2628(08)60158-5.

[32]. Farkas J (1988) Irradiation of dry food ingredients. CRC Press, Inc., Boca Raton, FL, pp. 34-42.

[33]. Sharma A, Ghanekar AS, Padwal-Desai SR, Nadkarni GB (1984) Microbiological status and antifungal properties of irradiated spices. J Agric Food Chem 32:1061-1063.

[34]. Bandekar JR, Jadhav SS, Shashidhar R, Hajare S, Sharma A (2003) Use of irradiation to ensure hygienic quality of fresh, pre-cut fruits and vegetables and other minimally processed food of plant origin. In: Use of irradiation to ensure the hygienic quality of fresh, pre-cut fruits and vegetables and other minimally processed food of plant origin. Proceedings of a final research coordination meeting organized by the Joint FAO/IAEA Programme of Nuclear Techniques in Food and Agriculture and held in Islamabad, Pakistan, 22-30 July 2005. Journal of IAEA, TECDOC-1530: 170-187.

[35]. Landgraf M, Goularte L, Martins C, Cestarijrt A, Nunes T, Aragon-Alegro L, Destro M, Behrens J, Vizeu D, Hutzler B ( 2006) Use of irradiation to improve the microbiological safety of minimally processed fruits and vegetables. In: Use of irradiation to ensure the hygienic quality of fresh, pre-cut fruits and vegetables and other minimally processed food of plant origin. Proceedings of a final research coordination meeting organized by the Joint FAO/IAEA Programme of Nuclear Techniques in Food and Agriculture and held in Islamabad, Pakistan, 22-30 July 2005. Journal of IAEA, TECDOC-1530: Journal of IAEA 1530:41-59.

[36]. AL Bayatti KK (2009) The effect of ionizing radiation on microorganism in some spices. Iraqi J Vet Med 33:149-154.

Tables

Table 1. Dry matter contents of black pepper and clove irradiated with various doses of $\gamma$-radiation.

\begin{tabular}{|c|c|c|c|c|c|c|c|c|c|c|c|c|}
\hline $\begin{array}{l}\text { Dry matter }(\% \\
\text { w/w) of spices }\end{array}$ & & $0.0 \mathrm{kGy}$ & & & $\begin{array}{l}5.0 \\
\mathrm{kGy}\end{array}$ & & & $\begin{array}{l}10.0 \\
k G y\end{array}$ & & & $\begin{array}{l}20.0 \\
\mathrm{kGy}\end{array}$ & \\
\hline $\begin{array}{l}\text { Storage period in } \\
\text { months }\end{array}$ & 0 & 3 & 6 & 0 & 3 & 6 & 0 & 3 & 6 & 0 & 3 & 6 \\
\hline Spices & & & & & & & & & & & & \\
\hline Black pepper & $\begin{array}{l}87.60 \\
\pm 2.25\end{array}$ & $\begin{array}{l}90.27 \pm 2 . \\
33\end{array}$ & $\begin{array}{l}91.4 \\
1 \pm 2 . \\
25\end{array}$ & $\begin{array}{l}87.3 \\
7 \pm 2 . \\
25\end{array}$ & $\begin{array}{l}90.40 \\
\pm 2.33\end{array}$ & $\begin{array}{l}91.61 \pm \\
2.36\end{array}$ & $\begin{array}{l}88.4 \\
0 \pm 2 . \\
28\end{array}$ & $\begin{array}{l}91.4 \\
1 \pm 2 . \\
35\end{array}$ & $\begin{array}{l}92.59 \\
\pm 2.39\end{array}$ & $\begin{array}{l}87.4 \\
6 \pm 2 \\
60\end{array}$ & $\begin{array}{l}90.23 \pm \\
2.33\end{array}$ & $\begin{array}{l}92.62 \pm \\
2.37\end{array}$ \\
\hline Clove & $\begin{array}{l}88.40 \\
\pm 2.29\end{array}$ & $\begin{array}{l}91.07 \pm 2 . \\
32\end{array}$ & $\begin{array}{l}91.3 \\
4 \pm 2 . \\
35\end{array}$ & $\begin{array}{l}88.1 \\
0 \pm 2 . \\
28\end{array}$ & $\begin{array}{l}91.13 \\
\pm 2.35\end{array}$ & $\begin{array}{l}91.34 \pm \\
2.35\end{array}$ & $\begin{array}{l}88.3 \\
0 \pm 2 . \\
30\end{array}$ & $\begin{array}{l}91.3 \\
3 \pm 3 . \\
33\end{array}$ & $\begin{array}{l}92.55 \\
\pm 2.39\end{array}$ & $\begin{array}{l}88.2 \\
1 \pm 2 \\
40\end{array}$ & $\begin{array}{l}90.98 \pm \\
2.35\end{array}$ & $\begin{array}{l}92.87 \pm \\
2.37\end{array}$ \\
\hline
\end{tabular}

* All determinations are the mean of 5 samples; the results are expressed as the mean \pm SD (standard deviation), (P $<0.05)$

Table 2. Total essential oils contents of black pepper irradiated with various doses of $\gamma$-radiation

\begin{tabular}{|l|l|l|l|l|l|l|l|l|l|l|l|l|}
\hline $\begin{array}{l}\text { Dose response } \\
\text { of irradiation of } \\
\text { essential oils }\end{array}$ & & $\begin{array}{l}0.0 \\
\mathrm{kGy}\end{array}$ & & & $\begin{array}{l}5.0 \\
\mathrm{kGy}\end{array}$ & & & $\begin{array}{l}10.0 \\
\mathrm{kGy}\end{array}$ & & & $\begin{array}{l}20.0 \\
\mathrm{kGy}\end{array}$ & \\
\hline $\begin{array}{l}\text { Storage period } \\
\text { in months }\end{array}$ & 0 & 3 & 6 & 0 & 3 & 6 & 0 & 3 & 6 & 0 & 3 & 6 \\
\hline $\begin{array}{l}\text { CompoundsIn } \\
\text { Black Pepper, \% }\end{array}$ & & & & & & & & & & & \\
\hline$\propto$-Tujene & $\begin{array}{l}1.69 \\
\pm 0.13\end{array}$ & $\begin{array}{l}1.09 \pm \\
0.13\end{array}$ & $\begin{array}{l}1.0 \pm 0.1 \\
0\end{array}$ & $\begin{array}{l}0.64 \pm \\
0.09\end{array}$ & $\begin{array}{l}0.62 \pm \\
0.10\end{array}$ & $\begin{array}{l}0.6 \pm 0 . \\
10\end{array}$ & $\begin{array}{l}1.53 \pm 0 \\
.15\end{array}$ & $\begin{array}{l}1.54 \pm \\
0.14\end{array}$ & $\begin{array}{l}1.0 \pm 0 . \\
13\end{array}$ & $\begin{array}{l}1.29 \pm \\
0.14\end{array}$ & $\begin{array}{l}1.89 \pm \\
0.14\end{array}$ & $\begin{array}{l}1.75 \pm 0 \\
.12\end{array}$ \\
\hline
\end{tabular}

DOI: $10.9790 / 2402-1009030107$

www.iosrjournals.org

5| Page 
Study on the Use of Ionizing Radiation for the Preservation of Spices

\begin{tabular}{|l|l|l|l|l|l|l|l|l|l|l|l|l|}
\hline$\propto$-Pinene & $8.2 \pm 0$. & $8.22 \pm$ & $8.11 \pm 0$. & $8.0 \pm 0$ & $8.01 \pm$ & $7.95 \pm 0$ & $6.01 \pm 0$ & $6.1 \pm 0$ & $6.01 \pm$ & $6.8 \pm 0$. & $6.95 \pm$ & $6.0 \pm 0$. \\
& 60 & 0.61 & 69 & .40 & 0.43 & .41 & .91 & .89 & 0.92 & 97 & 0.80 & 79 \\
\hline Sabinene & $22.3 \pm 0$ & 22.29 & $22.31 \pm$ & 22.05 & $22.0 \pm$ & $21.9 \pm 0$ & $22.46 \pm$ & 22.49 & $22.5 \pm$ & $21.9 \pm$ & $21.0 \pm$ & 22.0 \\
& .23 & \pm 0.17 & 0.21 & \pm 0.14 & 0.12 & .12 & 0.25 & \pm 0.23 & 0.29 & 0.23 & 0.22 & \pm 0.22 \\
\hline$\beta \beta$-Pinene & $8.23 \pm 0$ & $8.25 \pm$ & $8.24 \pm 0$. & $8.22 \pm$ & $8.19 \pm$ & $8.0 \pm 0$. & $8.07 \pm 0$ & $8.3 \pm 0$ & $8.29 \pm$ & $7.83 \pm$ & $7.63 \pm$ & $7.43 \pm 0$ \\
& .23 & 0.22 & 22 & 0.20 & 0.23 & 16 & .21 & .21 & 0.23 & 0.21 & 0.20 & .20 \\
\hline D-carene & $15.9 \pm 0$ & 15.21 & $15.15 \pm$ & 15.85 & 15.85 & $15.8 \pm 0$ & $15.1 \pm 0$ & $15.5 \pm$ & 15.25 & $15.5 \pm$ & $15.9 \pm$ & $15.75 \pm$ \\
& .13 & \pm 0.11 & 0.12 & \pm 0.14 & \pm 0.14 & .10 & .14 & 0.16 & \pm 0.16 & 0.14 & 0.15 & 0.14 \\
\hline Limonene & $22.8 \pm 0$ & 22.75 & $22.81 \pm$ & $23.8 \pm$ & 23.75 & $23.8 \pm 0$ & $23.6 \pm 0$ & 23.62 & $23.6 \pm$ & $23.4 \pm$ & 23.81 & $23.72 \pm$ \\
& .12 & \pm 0.22 & 0.21 & 0.16 & \pm 0.20 & .20 & .20 & \pm 0.23 & 0.26 & 0.20 & \pm 0.22 & 0.22 \\
\hline Linalool & $1.3 \pm 0$. & $1.45 \pm$ & $1.52 \pm 0$. & $1.15 \pm$ & $1.13 \pm$ & $1.12 \pm 0$ & $1.46 \pm 0$ & $1.64 \pm$ & $1.51 \pm$ & $1.81 \pm$ & $1.13 \pm$ & $1.0 \pm 0$. \\
& 07 & 0.08 & 11 & 0.08 & 0.07 & .07 & .08 & 0.11 & 0.12 & 0.09 & 0.10 & 10 \\
\hline$\propto$-Copaene & $6.85 \pm 0$ & $6.86 \pm$ & $6.8 \pm 0.2$ & $6.85 \pm$ & $6.82 \pm$ & $6.8 \pm 0$. & $6.71 \pm 0$ & $6.75 \pm$ & $6.95 \pm$ & $6.35 \pm$ & $6.41 \pm$ & $6.32 \pm 0$ \\
& .22 & 0.22 & 4 & 0.20 & 0.20 & 19 & .21 & 0.21 & 0.23 & 0.20 & 0.19 & .19 \\
\hline BCaryophyllene & $12.14 \pm$ & 12.34 & $12.35 \pm$ & $12.0 \pm$ & $12 \pm 0$. & $11 \pm 0.1$ & $12.24 \pm$ & 12.24 & 12.19 & 12.03 & 12.18 & $12.0 \pm 0$ \\
& 0.12 & \pm 0.13 & 0.13 & 0.10 & 11 & 1 & 0.12 & \pm 0.13 & \pm 0.15 & \pm 0.12 & \pm 0.12 & .13 \\
\hline Terpinen-4o1 & $0.5 \pm 0$. & $0.55 \pm$ & $0.51 \pm 0$. & $0.5 \pm 0$ & $0.5 \pm 0$ & $0.45 \pm 0$ & $1.34 \pm 0$ & $1.36 \pm$ & $1.35 \pm$ & $1.07 \pm$ & $1.0 \pm 0$ & $0.91 \pm 0$ \\
& 22 & 0.21 & 19 & .22 & .20 & .20 & .23 & 0.23 & 0.24 & 0.20 & .22 & .22 \\
\hline Total & $99.91 \pm$ & 99.01 & $98.8 \pm 0$. & 99.06 & 98.87 & $97.42 \pm$ & $98.52 \pm$ & 98.89 & 98.65 & 97.98 & $97.9 \pm$ & $96.88 \pm$ \\
& 0.02 & \pm 0.21 & 22 & \pm 0.17 & \pm 0.18 & 0.22 & 0.25 & \pm 0.25 & \pm 0.27 & \pm 0.25 & 0.23 & 0.23 \\
\hline
\end{tabular}

All determinations are the mean of 5 samples; the results are expressed as the mean \pm SD (standard deviation), (P $<0.05$

Table 3. Total essential oils contents ofclove irradiated with various doses of $\gamma$-radiation

\begin{tabular}{|c|c|c|c|c|c|c|c|c|c|c|c|c|}
\hline $\begin{array}{l}\text { Dose response } \\
\text { of irradiation of }\end{array}$ & & $\begin{array}{l}0.0 \\
\mathrm{kGy}\end{array}$ & & & $\begin{array}{l}5.0 \\
\text { kGy }\end{array}$ & & & $\begin{array}{l}10.0 \\
\text { kGy }\end{array}$ & & & $\begin{array}{l}20.0 \\
\text { kGy }\end{array}$ & \\
\hline $\begin{array}{l}\text { Storage period } \\
\text { in months }\end{array}$ & 0 & 3 & 6 & 0 & 3 & 6 & 0 & 3 & 6 & 0 & 3 & 6 \\
\hline $\begin{array}{l}\text { Compounds in } \\
\text { Clove \% }\end{array}$ & & & & & & & & & & & & \\
\hline Eugenol & $\begin{array}{l}73.5 \pm \\
1.34\end{array}$ & $\begin{array}{l}73.5 \pm \\
1.34\end{array}$ & $\begin{array}{r}73.29 \\
\pm 1.89\end{array}$ & $\begin{array}{r}72.95 \\
\pm 1.59 \\
\end{array}$ & $\begin{array}{l}72.94 \pm \\
1.58\end{array}$ & $\begin{array}{l}72.9 \pm \\
1.53\end{array}$ & $\begin{array}{l}73.66 \pm 1 . \\
60\end{array}$ & $\begin{array}{l}73.65 \pm \\
1.60\end{array}$ & $\begin{array}{l}71.96 \\
\pm 1.61\end{array}$ & $\begin{array}{l}73.6 \pm \\
1.49\end{array}$ & $\begin{array}{r}73.2 \\
\pm 1.5 \\
\end{array}$ & $\begin{array}{l}73.0 \\
5 \pm 1 .\end{array}$ \\
\hline Eugenol acetate & $\begin{array}{l}10.81 \\
\pm 0.89 \\
\end{array}$ & $\begin{array}{l}10.80 \\
\pm 0.89 \\
\end{array}$ & $\begin{array}{l}10.78 \\
\pm 0.88 \\
\end{array}$ & $\begin{array}{l}10.68 \\
\pm 0.82 \\
\end{array}$ & $\begin{array}{l}10.67 \pm \\
0.82 \\
\end{array}$ & $\begin{array}{l}10.6 \pm \\
0.86\end{array}$ & $\begin{array}{l}10.92 \pm 0 . \\
88\end{array}$ & $\begin{array}{l}10.9 \pm 0 \\
.88\end{array}$ & $\begin{array}{l}10.90 \\
\pm 0.89\end{array}$ & $\begin{array}{l}10.71 \\
\pm 0.86 \\
\end{array}$ & $\begin{array}{l}10.6 \\
9 \pm 0 .\end{array}$ & $\begin{array}{l}10.5 \\
\pm 0.8 \\
\end{array}$ \\
\hline $\begin{array}{l}\beta- \\
\text { Caryophllene }\end{array}$ & $\begin{array}{l}4.56 \pm \\
0.36\end{array}$ & $\begin{array}{l}4.41 \pm \\
0.36\end{array}$ & $\begin{array}{l}4.39 \pm \\
0.39\end{array}$ & $\begin{array}{l}4.35 \pm \\
0.37\end{array}$ & $\begin{array}{l}4.3 \pm 0.3 \\
9\end{array}$ & $\begin{array}{l}4.22 \pm \\
0.43\end{array}$ & $\begin{array}{l}4.40 \pm 0.3 \\
3\end{array}$ & $\begin{array}{l}4.41 \pm 0 \\
.33\end{array}$ & $\begin{array}{l}4.40 \pm \\
0.35\end{array}$ & $\begin{array}{l}4.26 \pm \\
0.36\end{array}$ & $\begin{array}{l}4.33 \\
\pm 0.3\end{array}$ & $\begin{array}{l}4.30 \\
\pm 0.3 \\
\end{array}$ \\
\hline $\begin{array}{l}\text { Caryophyllene } \\
\text { oxide }\end{array}$ & $\begin{array}{l}2.57 \pm \\
0.20\end{array}$ & $\begin{array}{l}2.5 \pm 0 . \\
19\end{array}$ & $\begin{array}{l}2.33 \pm \\
0.17\end{array}$ & $\begin{array}{l}2.25 \pm \\
0.20\end{array}$ & $\begin{array}{l}2.2 \pm 0.1 \\
8\end{array}$ & $\begin{array}{l}2.2 \pm 0 . \\
18\end{array}$ & $\begin{array}{l}2.41 \pm 0.2 \\
0\end{array}$ & $\begin{array}{l}2.43 \pm 0 \\
.20\end{array}$ & $\begin{array}{l}2.41 \pm \\
0.19\end{array}$ & $\begin{array}{l}2.37 \pm \\
0.18\end{array}$ & $\begin{array}{l}2.67 \\
\pm 0.2\end{array}$ & $\begin{array}{l}2.50 \\
\pm 0.2\end{array}$ \\
\hline$\propto$ - Humulene & $\begin{array}{l}1.56 \pm \\
0.12\end{array}$ & $\begin{array}{l}1.5 \pm 0 . \\
11\end{array}$ & $\begin{array}{l}1.79 \pm \\
0.11\end{array}$ & $\begin{array}{l}1.5 \pm 0 \\
.12\end{array}$ & $\begin{array}{l}1.5 \pm 0.1 \\
0\end{array}$ & $\begin{array}{l}1.59 \pm \\
0.13\end{array}$ & $\begin{array}{l}1.34 \pm 0.1 \\
3\end{array}$ & $\begin{array}{l}1.35 \pm 0 \\
.12\end{array}$ & $\begin{array}{l}1.35 \pm \\
0.11\end{array}$ & $\begin{array}{l}1.34 \pm \\
0.13\end{array}$ & $\begin{array}{l}1.54 \\
\pm 0.1\end{array}$ & $\begin{array}{l}1.42 \\
\pm 0.1\end{array}$ \\
\hline$\propto$-Pinene & $\begin{array}{l}0.91 \pm \\
0.09\end{array}$ & $\begin{array}{l}0.85 \pm \\
0.08\end{array}$ & $\begin{array}{l}0.81 \pm \\
0.06\end{array}$ & $\begin{array}{l}0.66 \pm \\
0.09\end{array}$ & $\begin{array}{l}0.65 \pm 0 . \\
07\end{array}$ & $\begin{array}{l}0.62 \pm \\
0.05\end{array}$ & $\begin{array}{l}0.85 \pm 0.0 \\
6\end{array}$ & $\begin{array}{l}0.82 \pm 0 \\
.05\end{array}$ & $\begin{array}{l}0.81 \pm \\
0.06\end{array}$ & $\begin{array}{l}0.61 \pm \\
0.09\end{array}$ & $\begin{array}{l}0.80 \\
\pm 0.0\end{array}$ & $\begin{array}{l}0.81 \\
\pm 0.0\end{array}$ \\
\hline Ledol & $\begin{array}{l}1.49 \pm \\
0.11\end{array}$ & $\begin{array}{l}1.53 \pm \\
0.10\end{array}$ & $\begin{array}{l}1.53 \pm \\
0.10\end{array}$ & $\begin{array}{l}1.45 \pm \\
0.12\end{array}$ & $\begin{array}{l}1.44 \pm 0 . \\
12\end{array}$ & $\begin{array}{l}0.05 \\
0.11 \pm\end{array}$ & $\begin{array}{l}0 \\
0\end{array}$ & $\begin{array}{l}1.33 \pm 0 \\
.10\end{array}$ & $\begin{array}{l}1.00 \\
0.12 \pm\end{array}$ & $\begin{array}{l}1.31 \pm \\
0.17\end{array}$ & $\begin{array}{l}1.39 \\
\pm 0.1\end{array}$ & $\begin{array}{l}1.37 \\
\pm 0.1\end{array}$ \\
\hline Linalool & $\begin{array}{l}0.89 \pm \\
0.07\end{array}$ & $\begin{array}{l}0.89 \pm \\
0.07\end{array}$ & $\begin{array}{l}0.88 \pm \\
0.08\end{array}$ & $\begin{array}{l}0.75 \pm \\
0.03\end{array}$ & $\begin{array}{l}0.71 \pm 0 . \\
04\end{array}$ & $\begin{array}{l}0.65 \pm \\
0.05\end{array}$ & $\begin{array}{l}0.86 \pm 0.0 \\
3\end{array}$ & $\begin{array}{l}0.85 \pm 0 \\
.03\end{array}$ & $\begin{array}{l}0.86 \pm \\
0.02\end{array}$ & $\begin{array}{l}0.60 \pm \\
0.03\end{array}$ & $\begin{array}{l}0.67 \\
\pm 0.0\end{array}$ & $\begin{array}{l}0.11 \\
\pm 0.0\end{array}$ \\
\hline $\begin{array}{l}\text { Methyl } \\
\text { salicylate }\end{array}$ & $\begin{array}{l}0.14 \pm \\
0.11\end{array}$ & $\begin{array}{l}0.16 \pm \\
0.11\end{array}$ & $\begin{array}{l}0.15 \pm \\
0.12\end{array}$ & $\begin{array}{l}0.12 \pm \\
0.10\end{array}$ & $\begin{array}{l}0.12 \pm 0 . \\
09\end{array}$ & $\begin{array}{l}0.11 \pm \\
0.09\end{array}$ & $\begin{array}{l}0.13 \pm 0.1 \\
1\end{array}$ & $\begin{array}{l}0.15 \pm 0 \\
.11\end{array}$ & $\begin{array}{l}0.15 \pm \\
0.13\end{array}$ & $\begin{array}{l}0.11 \pm \\
0.11\end{array}$ & $\begin{array}{l}0.12 \\
\pm 0.1\end{array}$ & $\begin{array}{l}0.13 \\
\pm 0.1\end{array}$ \\
\hline 2-Nonanone & $\begin{array}{l}0.02 \pm \\
0.001\end{array}$ & $\begin{array}{l}0.04 \pm \\
0.002\end{array}$ & $\begin{array}{l}0.03 \pm \\
0.001\end{array}$ & $\begin{array}{l}0.05 \pm \\
0.002\end{array}$ & $\begin{array}{l}0.05 \pm 0 . \\
001\end{array}$ & $\begin{array}{l}0.03 \pm \\
0.002\end{array}$ & $\begin{array}{l}0.04 \pm 0.0 \\
03\end{array}$ & $\begin{array}{l}0.05 \pm 0 \\
.006\end{array}$ & $\begin{array}{l}0.03 \pm \\
0.006\end{array}$ & $\begin{array}{l}0.11 \\
0.05 \pm \\
0.003\end{array}$ & $\begin{array}{l} \pm .04 \\
\pm 0.0\end{array}$ & $\begin{array}{l} \pm .04 \\
\pm 0.0\end{array}$ \\
\hline TOTAL & $\begin{array}{l}96.45 \\
\pm 0.33\end{array}$ & $\begin{array}{l}96.18 \\
\pm 0.32\end{array}$ & $\begin{array}{l}95.98 \\
\pm 0.39\end{array}$ & $\begin{array}{l}94.76 \\
\pm 0.34\end{array}$ & $\begin{array}{l}94.58 \pm \\
0.33\end{array}$ & $\begin{array}{l}94.33 \\
\pm 0.34\end{array}$ & $\begin{array}{l}95.94 \pm 0 . \\
34\end{array}$ & $\begin{array}{l}95.94 \pm \\
0.34\end{array}$ & $\begin{array}{l}94.20 \\
\pm 0.34\end{array}$ & $\begin{array}{l}94.96 \\
\pm 0.34\end{array}$ & $\begin{array}{l}95.4 \\
5 \pm 0 .\end{array}$ & $\begin{array}{l}94.1 \\
0 \pm 0 .\end{array}$ \\
\hline
\end{tabular}

All determinations are the mean of 5 samples; the results are expressed as the mean \pm SD (standard deviation), (P < 0.05

Table 4. Microbiological quality of spices irradiated with various doses of $\gamma$-radiation

\begin{tabular}{|c|c|c|c|c|c|c|c|c|c|c|c|c|c|}
\hline \multirow[t]{3}{*}{ Spices } & \multirow[t]{3}{*}{$\begin{array}{l}\text { Dose } \\
\text { (kGy) }\end{array}$} & \multicolumn{3}{|c|}{$\begin{array}{l}\text { Escherichia coli ATCC } 35218 \\
(\log \mathrm{cfu} / \mathrm{g})\end{array}$} & \multicolumn{2}{|c|}{$\begin{array}{l}\text { Staphylococcus } \\
\text { ATCC25923 } \\
(\log \mathrm{cfu} / \mathrm{g})\end{array}$} & aureus & \multicolumn{3}{|c|}{$\begin{array}{l}\text { Klebsiella pnetumoniaestCC } \\
(\log \mathrm{cfu} / \mathrm{g})\end{array}$} & \multicolumn{3}{|c|}{$\begin{array}{l}\text { Yeast Candida albicans } \\
(\log \mathrm{cfu} / \mathrm{g})\end{array}$} \\
\hline & & \multicolumn{12}{|c|}{ Periods of storage in month } \\
\hline & & 0 & \begin{tabular}{|l|}
3 \\
\end{tabular} & 6 & 0 & 3 & 6 & 0 & 3 & 6 & 0 & 3 & 6 \\
\hline \multirow[t]{4}{*}{ Black Pepper } & 0 & $3.5 \times 10^{5}$ & $2.5 \times 10^{5}$ & $2.5 \times 10^{5}$ & $2.6 \times 10^{5}$ & $2.5 \times 10^{3}$ & $2.6 \times 10^{5}$ & $3.1 \times 10^{5}$ & $3.5 \times 10^{5}$ & $3.0 \times 10^{5}$ & $6.4 \times 10^{5}$ & $6.4 \times 10^{5}$ & $6.2 \times 10^{5}$ \\
\hline & 5 & $1.3 \times 10^{2}$ & $1.5 \times 10^{2}$ & $1.2 \times 10^{2}$ & $2.0 \times 10^{2}$ & $1.5 \times 10^{2}$ & $0.9 \times 10^{2}$ & $1.0 \times 10^{2}$ & $1.5 \times 10^{2}$ & $1.3 \times 10^{2}$ & $3.0 \times 10^{1}$ & $<10$ & $<10$ \\
\hline & 10 & $<10$ & $<10$ & $<10$ & $<10$ & $<10$ & $<10$ & $<10$ & $<10$ & $<10$ & $<10$ & $<10$ & $<10$ \\
\hline & 20 & $<10$ & $<10$ & $<10$ & $<10$ & $<10$ & $<10$ & $<10$ & $<10$ & $<10$ & $<10$ & $<10$ & $<10$ \\
\hline \multirow[t]{4}{*}{ Clove } & 0 & $1.5 \times 10^{4}$ & $1.5 \times 10^{4}$ & $1.0 \times 10^{4}$ & $2.5 \times 10^{4}$ & $2.5 \times 10^{4}$ & $1.5 \times 10^{4}$ & $2.0 \times 10^{4}$ & $1.5 \times 10^{4}$ & $1.5 \times 10^{4}$ & $3.9 \times 10^{4}$ & $3.5 \times 10^{2}$ & $3.5 \times 10^{2}$ \\
\hline & 5 & $0.5 \times 10^{2}$ & $0.5 \times 10^{4}$ & $0.5 \times 10^{1}$ & $1.5 \times 10^{2}$ & $1.5 \times 10^{2}$ & $0.5 \times 10^{1}$ & $1.2 \times 10^{4}$ & $0.9 \times 10^{4}$ & $0.5 \times 10^{4}$ & $1.0 \times 10^{4}$ & $<10$ & 410 \\
\hline & 10 & $<10$ & $<10$ & $<10$ & $<10$ & $<10$ & $<10$ & $<10$ & $<10$ & $<10$ & $<10$ & $<10$ & $<10$ \\
\hline & 20 & $<10$ & $<10$ & $<10$ & $<10$ & $<10$ & $<10$ & $<10$ & $<10$ & $<10$ & $<10$ & $<10$ & $<10$ \\
\hline
\end{tabular}


